\title{
COMBINED EFFECT OF SELECTED MINERAL FIBRES AND TOBACCO SMOKE ON RESPIRATORY TRACT IN RATS
}

\author{
Marta Hurbánková, Dominika Hrašková, Milan Beňo, Silvia Černá, Soňa Wimmerová, Štefánia Moricová \\ Laboratory of Respiratory Toxicology, Faculty of Public Health, Slovak Medical University in Bratislava, Bratislava, Slovak Republic
}

\begin{abstract}
SUMMARY
The rats were inhaling amosite and wollastonite fibres at two concentrations $\left(30\right.$ and $\left.60 \mathrm{mg} / \mathrm{m}^{3}\right)$ one hour every second day and cigarette smoke of 3 cigarettes per day (with the exception of Saturdays and Sundays). They were sacrificed after 6 month of exposure. Bronchoalveolar lavage (BAL) was performed and selected inflammatory and cytotoxic parameters were examined. Amosite: inflammatory parameters were the most changed after $60 \mathrm{mg} / \mathrm{m}^{3}$ in both groups with or without smoking; the cytotoxic parameters were strongly influenced by smoking. Wollastonite (asbestos substitute) inhalation confirmed lower inflammatory and cytotoxic effects on all examined animal groups in comparison with amosite.
\end{abstract}

Key words: fibrous dusts, cigarette smoke, combined effect, bronchoalveolar lavage, inflammatory and cytotoxic parameters, inhalation exposure

Address for correspondence: M. Hurbánková, Slovak Medical University, Faculty of Public Health, Laboratory of Respiratory Toxicology, Limbová 12, 83303 Bratislava, Slovak Republic. E-mail: marta.hurbankova@szu.sk

\section{INTRODUCTION}

The effect of industrial fibrous dusts on the respiratory system represents a potential environmental and occupational health hazard for humans. Long-time exposure to asbestos can cause pleural plaques, asbestosis and oncological diseases. These facts point out the importance of research activities aiming at the study of the health effect of fibrous substitutes as well as combined effect with other noxious materials. This study provides information about the dose-response relationships after the inhalation of two concentration levels of amosite asbestos and wollastonite alone or in combination with daily exposure to cigarette smoke. The aim of our study was to find and compare the combined effect of amosite or wollastonite (asbestos substitute) to cigarette smoke on the selected inflammatory and cytotoxic parameters.

\section{MATERIALS AND METHODS}

\begin{abstract}
Animal Conditions
Male Fisher 344 rats were supplied by the Charles River Company, Germany. Following two weeks of quarantine, at the start of exposures the animals weighed 191.2 (s.d. 10.4) grams. All animals were maintained under non-infectious laboratory conditions at $22+2{ }^{\circ} \mathrm{C}, 45 \%$ of relative humidity, under natural light and normal light/dark photoperiodicity and in air-conditioned rooms using the unit WOLF KG 100 (WOLF - Clima Technic, GmbH, Mainburg, Germany).
\end{abstract}

\section{Fibre Exposure}

The animals were fed by standard commercial laboratory pellets ST1 (TOP - Dovo, Horne Dubove, the Slovak Republic) and water ad libitum. The period of exposures lasted 175 days (6 months). Animals were inhaling amosite asbestos or wollastonite fibres in a nose-only inhalation device (In-Tox, USA). Amphibole asbestos - amosite and wollastonite fibres belong to naturally occurring silicate inorganic fibres. Wollastonite is used as a substitute of asbestos.

Solid aerosol was produced in two concentrations: $30 \mathrm{mg} / \mathrm{m}^{3}$ air and $60 \mathrm{mg} / \mathrm{m}^{3}$ air for one hour per exposure. Exposure of animal groups of dusts proceeded every second day, including all holidays. Saturdays and Sundays were held free of exposures. Six groups, each of 11 animals were exposed to:

- $60 \mathrm{mg} / \mathrm{m}^{3}$ amosite fibres for one hour every two days, combined with exposure to mainstream smoke from three cigarettes daily;

- $60 \mathrm{mg} / \mathrm{m}^{3}$ amosite fibres for one hour every two days;

- $30 \mathrm{mg} / \mathrm{m}^{3}$ amosite fibres for one hour every two days, combined with exposure to mainstream smoke from three cigarettes daily;

- $30 \mathrm{mg} / \mathrm{m}^{3}$ amosite fibres for one hour every two days; exposure to mainstream smoke from three cigarettes daily plus immobilization stress as for animals exposed to dust;

- immobilization stress as for animals exposed to dust.

\section{Cigarette Smoke Exposure}

Standard research cigarettes of the 1R1 type (Tobacco and Health Research Institute - THRI, Lexington, KY, USA) were used in all experiments. A whole-body actively ventilated exposure chamber was used, with a cigarette smoke generator and pumps (THRI, Lexington, KY, USA) allowing all smoker animal groups to breathe at the same time diluted main-stream tobacco smoke at the target concentration of $30 \mathrm{mg}$ of total particulate matter (TPM) per $\mathrm{m}^{3}$ air for one hour daily (an exposure requiring to burn three cigarettes). 
Table 1. Length, diameter and percentage of fibers in wollastonite fibres

\begin{tabular}{|c|c|}
\hline Diameter $[\mu \mathrm{m}]$ & $\%$ \\
\hline$<1$ & 22 \\
\hline$=1$ & 47 \\
\hline$>1,<3$ & 21 \\
\hline$=3$ & 6 \\
\hline$>3$ & 4 \\
\hline Length $[\mu \mathrm{m}]$ & $\%$ \\
\hline $1-10$ & 48 \\
\hline $11-30$ & 40 \\
\hline$>30$ & 12 \\
\hline
\end{tabular}

Table 2. Length, diameter and percentage of fibers in amosite fibres

\begin{tabular}{|c|c|c|}
\hline Length $[\mu \mathrm{m}]$ & $\%$ & Diameter $[\mu \mathrm{m}]$ \\
\hline$<20$ & 5 & \multirow{2}{*}{0.71} \\
\hline $20-30$ & 75 & \\
\hline$>30$ & 20 & \\
\hline
\end{tabular}

\section{BAL Parameters}

Six months after beginning of the inhalation exposures, the animals were anesthetised with thiopental $(150 \mathrm{mg} / \mathrm{kg}$ of animal), exsanguinated by cutting the vena cava caudalis and bronchoalveolar lavage (BAL) was performed. The trachea was cannulated, and the lungs were washed 5 times with $5 \mathrm{ml}$ of saline solution.

The following BAL parameters were examined:

Inflammatory response biomarkers

- total cell count/ml BAL fluid

- alveolar macrophages (AM) count/ml BAL fluid

- differential cell count (AM, lymphocytes - Ly, granulocytes - Gr)

- cytotoxic parameters

- phagocytic activity of AM

- viability of AM

- lactate dehydrogenase activity (in the cell-free lavage fluid)
- acid phosphatase activity (in the cell-free lavage fluid and in the BAL cell suspension)

- the cathepsin D activity (in the cell-free lavage fluid and in the BAL suspension).

Methods are described in works of Hurbánková and Kaiglová, and Černá et al. $(1,2)$. The results were statistically evaluated using the Mann Whitney's test.

\section{RESULTS}

Table 3 shows inflammatory BAL parameters after inhalation of amosite fibres alone or in the combination with tobacco smoke. Inflammatory parameters were the most changed after the dose of $60 \mathrm{mg} / \mathrm{m}^{3}$ in combined group (amosite exposure and tobacco smoke).

Tobacco smoke alone induced changes in inflammatory parameters. It confirms that smoking alone might play an important role in inflammatory processes.

Table 4 presents the measurement of cytotoxic parameters following exposure to amosite, or amosite and tobacco smoke. Smoking alone caused some changes of cytotoxic parameters and intensified the harmful effect of amosite exposure. Mild dose dependence between $30 \mathrm{mg} / \mathrm{m}^{3}$ and $60 \mathrm{mg} / \mathrm{m}^{3}$ in groups without tobacco smoke was seen.

Table 5 shows inflammatory BAL parameters after inhalation of wollastonite fibres alone or in the combination with tobacco smoke. After exposure to wollastonite only, there were no changes in examined parameters. In the group "tobacco smoke alone" statistically significant increase of immature AM forms and multinuclear cells (\%) were found. Combined significant effect was seen in immature forms of AM in both doses only.

Table 6 presents the measurement of cytotoxic parameters following exposure to wollastonite, or wollastonite and tobacco smoke. For animals exposed to wollastonite alone significantly increased levels of Catepsin $\mathrm{D}\left(\mathrm{U}_{\mathrm{tyr}} / 10^{6}\right.$ cells) in both doses were investigated; tobacco smoke alone significantly decreased phagocytic activity of AM only and statistically significant combined effect was found in the levels of Cathepsin $\mathrm{D}\left(\mathrm{U}_{\mathrm{tyr}} / 10^{6}\right.$ cells $)$ after exposure to both doses.

Table 3. Amosite - inhalation exposure with/without tobacco smoke Inflammatory response parameters in BAL

\begin{tabular}{|l|c|c|c|c|c|c|}
\hline \multirow{2}{*}{ BAL parameters } & \multicolumn{3}{|c|}{ Fibres alone } & \multicolumn{3}{c|}{ Fibres/tobacco smoke } \\
\cline { 2 - 7 } & control & $30 \mathrm{mg} / \mathrm{m}^{3}$ & $60 \mathrm{mg} / \mathrm{m}^{3}$ & $\begin{array}{c}\text { tobacco smoke } \\
\text { alone }\end{array}$ & $\begin{array}{c}\text { tobacco smoke }+ \\
\text { fibres } 30 \mathrm{mg} / \mathrm{m}^{3}\end{array}$ & $\begin{array}{c}\text { tobacco smoke }+ \\
\text { fibres } 60 \mathrm{mg} / \mathrm{m}^{3}\end{array}$ \\
\hline $\mathrm{n}$ & 7 & 7 & 7 & 7 & 7 & 6 \\
\hline Total cell count $\times 10^{3} / \mathrm{ml}$ BALF & $216.67 \pm 11.30$ & $223.00 \pm 4.36$ & $240.00 \pm 7.75$ & $241.43 \pm 27.51$ & $261.00 \pm 23.31$ & $283.00 \pm 7.68 \uparrow^{* *}$ \\
\hline AM count $\times 10^{3} / \mathrm{mlBALF}$ & $158.57 \pm 8.14$ & $154.28 \pm 7.59$ & $143.57 \pm 7.13$ & $144.28 \pm 21.89$ & $137.50 \pm 17.31$ & $114.17 \pm 6.76 \downarrow^{* *}$ \\
\hline Ly (\%) & $2.86 \pm 0.26$ & $4.57 \pm 0.61 \uparrow^{*}$ & $7.57 \pm 1.27 \uparrow^{* *}$ & $3.43 \pm 0.42$ & $4.43 \pm 0.61$ & $7.00 \pm 0.69 \uparrow^{* * *}$ \\
\hline AM (\%) & $96.71 \pm 0.36$ & $94.57 \pm 0.65 \downarrow^{*}$ & $92.29 \pm 1.36 \downarrow^{*}$ & $95.14 \pm 0.46 \downarrow^{*}$ & $94.14 \pm 0.68 \downarrow^{* *}$ & $90.71 \pm 0.48 \downarrow^{* * *}$ \\
\hline PMN (\%) & $0.43 \pm 0.30$ & $0.85 \pm 0.26$ & $1.57 \pm 0.30 \uparrow^{*}$ & $1.43 \pm 0.48$ & $1.43 \pm 0.20 \uparrow^{*}$ & $2.29 \pm 0.47 \uparrow^{* *}$ \\
\hline Immature forms of AM (\%) & $31.71 \pm 3.31$ & $44.0 \pm 4.38 \uparrow^{*}$ & $43.14 \pm 6.27$ & $50.43 \pm 2.29 \uparrow^{* *}$ & $46.71 \pm 3.64 \uparrow^{*}$ & $51.86 \pm 4.63 \uparrow^{* *}$ \\
\hline Multinuclear cells (\%) & $0.485 \pm 0.096$ & $0.686 \pm 0.06$ & $0.971 \pm 0.1 \uparrow^{* *}$ & $0.457 \pm 0.084$ & $0.686 \pm 0.122$ & $0.714 \pm 0.156$ \\
\hline
\end{tabular}

Values represent means \pm SEM; Comparison of exposed groups with control group (without any exposure): ${ }^{*} p<0.05,{ }^{* *} p<0.01,{ }^{* * *} p<0.001 ; \uparrow:$ increase against contro group, $\downarrow$ : decrease against control group:

Abbreviations: AM - alveolar macrophages; Ly - lymphocytes; PMN - polymorphonuclear cells; BAL - bronchoalveolar lavage 
Table 4. Amosite - inhalation exposure with/without tobacco smoke Cytotoxic parameters in BAL

\begin{tabular}{|c|c|c|c|c|c|c|}
\hline \multirow[b]{2}{*}{ BAL parameters } & \multicolumn{3}{|c|}{ Fibres alone } & \multicolumn{3}{|c|}{ Fibres/tobacco smoke } \\
\hline & control & $30 \mathrm{mg} / \mathrm{m}^{3}$ & $60 \mathrm{mg} / \mathrm{m}^{3}$ & $\begin{array}{l}\text { tobacco smoke } \\
\text { alone }\end{array}$ & $\begin{array}{c}\text { tobacco smoke + } \\
\text { fibres } 30 \mathrm{mg} / \mathrm{m}^{3}\end{array}$ & $\begin{array}{l}\text { tobacco smoke + } \\
\text { fibres } 60 \mathrm{mg} / \mathrm{m}^{3}\end{array}$ \\
\hline$n$ & 7 & 7 & 7 & 7 & 7 & 6 \\
\hline Phagocytic activity of AM (\%) & $69.71 \pm 1.87$ & $70.57 \pm 1.99$ & $64.86 \pm 3.52$ & $47.4 \pm 5.63 \downarrow^{* *}$ & $53.14 \pm 4.27 \downarrow^{\star *}$ & $61.85 \pm 1.84 \downarrow^{*}$ \\
\hline Viabilty of living AM (\%) & $86.29 \pm 1.27$ & $87.29 \pm 0.68$ & $81.00 \pm 1.05 \downarrow^{*}$ & $83.86 \pm 0.26$ & $85.86 \pm 0.50$ & $79.80 \pm 2.13 \downarrow^{*}$ \\
\hline LDH $\mu$ kat/g proteins & $4.81 \pm 0.86$ & $4.43 \pm 0.19$ & $4.22 \pm 0.26$ & $4.09 \pm 0.73$ & $4.14 \pm 0.78$ & $3.31 \pm 0.24$ \\
\hline ACP nkat/g proteins & $65.77 \pm 10.57$ & $67.76 \pm 6.02$ & $49.45 \pm 3.76$ & $57.72 \pm 4.25$ & $52.52 \pm 4.38$ & $46.52 \pm 7.17$ \\
\hline ACP nkat $/ 10^{6}$ cells & $0.18 \pm 0.01$ & $0.18 \pm 0.03$ & $0.25 \pm 0.04$ & $0.17 \pm 0.02$ & $0.22 \pm 0.02$ & $0.27 \pm 0.05$ \\
\hline $\begin{array}{l}\text { Cathepsin D } \\
\mathrm{U}_{\mathrm{tyr}} / \mathrm{mg} \text { proteins }\end{array}$ & $77.70 \pm 7.59$ & $78.02 \pm 11.28$ & $83.63 \pm 5.53$ & $104.75 \pm 9.31$ & $105.42 \pm 7.17 \uparrow^{*}$ & $116.38 \pm 12.73$ \\
\hline $\begin{array}{l}\text { Cathepsin D } \\
\mathrm{U}_{\mathrm{tyy}} / 10^{6} \text { cells }\end{array}$ & $419.14 \pm 32.25$ & $455.53 \pm 38.79$ & $535.44 \pm 33.47 \uparrow^{*}$ & $604.27 \pm 26.88 \uparrow^{* *}$ & $681.63 \pm 27.57 \uparrow^{\star \star}$ & $779.58 \pm 47.04 \uparrow^{* *}$ \\
\hline
\end{tabular}

Table 5. Inflammatory response parameters in bronchoalveolar lavage fluid (BALF) following inhalation exposure to wollastonite with or without tobacco smoke

\begin{tabular}{|l|c|c|c|c|c|c|}
\hline \multirow{2}{*}{ BAL parameters } & \multicolumn{3}{|c|}{ Fibres alone } & \multicolumn{3}{c|}{ Fibres/tobacco smoke } \\
\cline { 2 - 7 } & control & $30 \mathrm{mg} / \mathrm{m}^{3}$ & $60 \mathrm{mg} / \mathrm{m}^{3}$ & $\begin{array}{c}\text { tobacco smoke } \\
\text { alone }\end{array}$ & $\begin{array}{c}\text { tobacco smoke }+ \\
\text { fibres } 30 \mathrm{mg} / \mathrm{m}^{3}\end{array}$ & $\begin{array}{c}\text { tobacco smoke }+ \\
\text { fibres } 60 \mathrm{mg} / \mathrm{m}^{3}\end{array}$ \\
\hline $\mathrm{n}$ & 7 & 7 & 7 & 7 & 7 & 6 \\
\hline Total cell count $\times 10^{3} / \mathrm{ml} \mathrm{BALF}$ & $218.33 \pm 7.27$ & $225.83 \pm 6.247$ & $236.00 \pm 15.12$ & $227.00 \pm 12.51$ & $231.00 \pm 15.36$ & $255.00 \pm 27.47$ \\
\hline AM count $\times 10^{3} / \mathrm{ml} \mathrm{BALF}$ & $152.86 \pm 10.17$ & $135.71 \pm 12.23$ & $172.14 \pm 22.44$ & $172.86 \pm 20.09$ & $158.57 \pm 15.26$ & $175.83 \pm 25.67$ \\
\hline Ly (\%) & $2.57 \pm 0.84$ & $3.14 \pm 0.76$ & $3.00 \pm 0.92$ & $3.00 \pm 0.31$ & $2.86 \pm 10.51$ & $3.33 \pm 0.33$ \\
\hline AM (\%) & $84.28 \pm 12.57$ & $96.14 \pm 0.96$ & $95.71 \pm 0.99$ & $96.00 \pm 0.58$ & $96.00 \pm 0.82$ & $95.33 \pm 0.42$ \\
\hline PMN (\%) & $0.57 \pm 0.20$ & $0.71 \pm 0.29$ & $1.28 \pm 0.29$ & $1.00 \pm 0.38$ & $1.14 \pm 0.40$ & $1.33 \pm 0.42$ \\
\hline Immature forms of AM (\%) & $20.57 \pm 2.19$ & $25.14 \pm 1.87$ & $26.29 \pm 2.29$ & $33.57 \pm 3.16 \uparrow^{* *}$ & $34.86 \pm 1.06 \uparrow *$ & $48.67 \pm 2.04 \uparrow^{* *}$ \\
\hline Multinuclear cells (\%) & $0.26 \pm 0.05$ & $0.4 \pm 0.01$ & $0.4 \pm 0.31$ & $0.77 \pm 0.09 \uparrow^{* *}$ & $0.4 \pm 10.09$ & $0.33 \pm 0.07$ \\
\hline
\end{tabular}

Values represent means \pm SEM; Comparison of exposed groups with control group (without any exposure): ${ }^{*} p<0.05,{ }^{* *} p<0.01,{ }^{* * *} p<0.001 ; \uparrow:$ increase against control group, $\downarrow$ : decrease against control group;

Abbreviations: AM - alveolar macrophages; BAL - bronchoalveolar lavage; Ly - lymphocytes; PMN - polymorphonuclear cells

Table 6. Cytotoxic parameters in bronchoalveolar lavage fluid (BALF) following inhalation exposure to wollastonite with or without tobacco smoke

\begin{tabular}{|c|c|c|c|c|c|c|}
\hline \multirow[b]{2}{*}{ BAL parameters } & \multicolumn{3}{|c|}{ Fibres alone } & \multicolumn{3}{|c|}{ Fibres/tobacco smoke } \\
\hline & control & $30 \mathrm{mg} / \mathrm{m}^{3}$ & $60 \mathrm{mg} / \mathrm{m}^{3}$ & $\begin{array}{l}\text { tobacco smoke } \\
\text { alone }\end{array}$ & $\begin{array}{l}\text { tobacco smoke + } \\
\text { fibres } 30 \mathrm{mg} / \mathrm{m}^{3}\end{array}$ & $\begin{array}{c}\text { tobacco smoke + } \\
\text { fibres } 60 \mathrm{mg} / \mathrm{m}^{3}\end{array}$ \\
\hline$n$ & 7 & 7 & 7 & 7 & 7 & 6 \\
\hline Phagocytic activity of AM (\%) & $56.80 \pm 3.43$ & $49.20 \pm 2.87$ & $47.57 \pm 4.00$ & $41.60 \pm 1.69 \square^{*}$ & $43.16 \pm 5.74$ & $52.33 \pm 4.17$ \\
\hline Viabilty of living AM (\%) & $89.29 \pm 1,43$ & $87.14 \pm 1.47$ & $86.57 \pm 1.34$ & $87.28 \pm 1.13$ & $87.43 \pm 21.28$ & $85.67 \pm 1.07$ \\
\hline LDH $\mu$ kat/g proteins & $3.66 \pm 0.58$ & $3,98 \pm 0.77$ & $4.30 \pm 0.74$ & $5.59 \pm 0.54$ & $5.96 \pm 20.91$ & $4.45 \pm 0.76$ \\
\hline ACP nkat/g proteins & $57.65 \pm 7.8$ & $60.26 \pm 7.05$ & $59.73 \pm 8.31$ & $84.35 \pm 13,21$ & $92.86 \pm 11.52 \uparrow^{*}$ & $63.29 \pm 18.13$ \\
\hline ACP nkat $/ 10^{6}$ cells & $0.17 \pm 0.01$ & $0.17 \pm 0.02$ & $0.16 \pm 0.01$ & $0.17 \pm 0.02$ & $0.18 \pm 0.01$ & $0.18 \pm 0.03$ \\
\hline $\begin{array}{l}\text { Cathepsin D } \\
U_{\text {tyr }} / m g \text { proteins }\end{array}$ & $63.54 \pm 9.67$ & $68.15 \pm 9.51$ & $73.17 \pm 11.84$ & $82.92 \pm 2.36$ & $70.9 \pm 9.95$ & $71.11 \pm 8.48$ \\
\hline $\begin{array}{l}\text { Cathepsin D } \\
U_{\text {tyl }} / 10^{6} \text { cells }\end{array}$ & $288.25 \pm 28.55$ & $403.06 \pm 28.90 \uparrow^{*}$ & $403.79 \pm 29.41 \uparrow^{*}$ & $325.57 \pm 9.93$ & $419.20 \pm 46.27 \uparrow^{*}$ & $437.54 \pm 41.64 \uparrow^{*}$ \\
\hline
\end{tabular}

Values represent means \pm SEM; Comparison of exposed groups with the control group (without any exposure): ${ }^{*} p<0.05,{ }^{* *} p<0.01,{ }^{* * *} p<0.001 ; \uparrow:$ increase against control group; $\downarrow$ : decrease against control group; enzyme activity expressed as $\mu \mathrm{mol}$ of $\mathrm{p}$-nitrophenol per hour per mg proteins;

Abbreviations: $\mathrm{LDH}$ - lactate dehydrogenase; $\mathrm{ACP}$ - acid phosphatase; $\mathrm{U}_{\mathrm{tyr}}-\mu \mathrm{g}$ of thyrosine released in an hour times 
Table 7. Dose dependence after inhalation exposure

\begin{tabular}{|c|c|c|c|c|}
\hline \multirow{2}{*}{ Fibres } & \multicolumn{2}{|c|}{ Inflammatory parameters } & \multicolumn{2}{|c|}{ Cytotoxic parameters } \\
\hline & without tobacco smoke & with tobacco smoke & without tobacco smoke & with tobacco smoke \\
\hline Amosite & + & + & \pm & $\pm^{*}$ \\
\hline Wollastonite & - & \pm & \pm & \pm \\
\hline
\end{tabular}

\section{DISCUSSION}

Increased numbers of BAL cells after asbestos or other particle exposure as a result of inflammatory response have been described by numerous authors. Prolonged inflammation can result in a number of processes that contribute to the induction of fibrosis or carcinogenesis $(1,3-5)$.

In our study, a statistically significantly increased number of BAL cells, in comparison with the control group, was observed in the smoker plus $60 \mathrm{mg} / \mathrm{m}^{3}$ fibre group (by $11.4 \%$ ) as well as in the corresponding-dose, non-smoker group (by about 16\%). This increase could be ascribed to the increase of lymphocyte population proportions. These changes were accompanied by an inverse change in the AM count in BAL, which significantly decreased in the same group exposed to combined higher dust plus cigarette smoke. A very similar but shorter exposure only to cigarette smoke has been reported to lead to a higher (35\%) difference of BAL cell counts in comparison with the control values (6).

The higher than control values of the proportions of polymorphonuclears (PMN), of lymphocytes percentage in BAL indicate the presence of inflammation in the lung at sacrifice. The magnitude of the increase of these parameters was dose-dependent.

Inhaled pollutants affect a number of key host defences, including pulmonary macrophage function. Similarly in experiments, rodents exposed to particulates such as smoke, carbon black $\mathrm{TiO}_{2}$, road dust etc., exhibit reduced AM phagocytosis (7). AM are the predominant cells present in BAL and changes in their number or function are important factors determining the lung inflammatory response and characterising the pathogenesis of such a response. A decrease in a macrophage number or phagocytic capacity may result in the reduction of the clearance of inhaled materials and thus can lead to an increase of the effective dose of the potentially injurious agent $(5,8,9)$. A significant reduction in the number of AM after i.t. instillation of amosite has been observed also in our previous experiments (1).

Associated with the inflammatory changes, a dose-dependent increase in multinuclear cells (MNC) proportions was found in BAL as well as in the lung tissue suspensions. MNC were increased after exposure (separate or in combination) to tobacco smoke as well as both fibre concentrations, nevertheless, they were statistically significant only after higher dose without smoking (10). Similarly, in comparison with the control, immature forms of AM in all exposed groups were increased.

Strong dose dependence decrease of AM viability (higher dose with and without smoking) as well as phagocytic activity of AM (all groups with smoking) was found in this experiment. That is in accordance with previously described effect of asbestos (1).
Increase of lactate dehydrogenase (LDH) and acid phosphatase (ACP) activity in extracellular fluids are generally accepted as a good marker of cell or tissue injury and therefore used for evaluation of the cytotoxic effect. We did not find significant changes in activities of measured mentioned enzymes in our experiment. Cathepsin D activity was significantly changed after amosite inhalation. These results are in good accordance with the work of Sjörstrand et al. (11).

Wollastonite inhalation confirmed the lower toxicity in comparison with asbestos. Significant changes were found only by measurement of cathepsin D activity in BAL cells and increased levels of immature forms in combined groups as well as multinuclear cell percentage in the group "tobacco smoke alone".

\section{CONCLUSIONS}

\section{Amosite}

- Inflammatory parameters were the most changed after $60 \mathrm{mg} / \mathrm{m}^{3}$ in combined group (amosite exposure and tobacco smoke).

- Tobacco smoke alone induced only some changes in inflammatory and cytotoxic parameters, but probably intensified the harmful effect of amosite exposure in our experiment.

- Dose dependence between $30 \mathrm{mg} / \mathrm{m}^{3}$ and $60 \mathrm{mg} / \mathrm{m}^{3}$ in groups without tobacco smoke was seen.

\section{Wollastonite}

- There were no significant changes of inflammatory parameters and no differences between the $30 \mathrm{mg} / \mathrm{m}^{3}$ and $60 \mathrm{mg} / \mathrm{m}^{3}$ concentration of wollastonite fibres. No dose dependence of BAL inflammatory parameters in this study was recorded in groups without smoking and in combined exposure groups.

- No dose dependence of the cytotoxic parameters in groups without or with tobacco smoke was observed.

- Influence of tobacco smoke on the cytotoxic and inflammatory parameters was not explicit.

\section{Acknowledgement}

The work was supported by an EU grant, contract No. QLK4-FIBRETOX project and by the Slovak Ministry of Health grant, contract No: MZ SR 2005/29-SZU-07.

\section{Conflict of Interests}

None declared 


\section{REFERENCES}

1. Hurbankova M, Kaiglova A. Compared effects of asbestos and wollastonite fibrous dusts on various biological parameters measured in bronchoalveolar lavage fluid. J Trace Microprobe Tech. 1999;17(2):233-43.

2. Černá S, Hurbánková M, Kováčiková Z, Beňo M, Wimmerová S. Lung cytotoxicity of combined exposure to refractory ceramic fibres and cigarette smoke. Biomed Pap Med Fac Univ Palacky Olomouc Czech Repub. 2005 Dec;149(2):381-4.

3. Morimoto Y, Tanaka I. In vivo studies of man-made mineral fibers fibrosis-related factors. Ind Health. 2001 Apr;39(2):106-13.

4. Greim H, Borm P, Schins R, Donaldson K, Driscoll K, Hartwig A, et al. Toxicity of fibers and particles. Report of the workshop held in Munich, Germany, 26-27 October 2000. Inhal Toxicol. 2001 Sep;13(9):737-54.

5. Stone V, Barlow PG, Hutchison GR, Brown DM. Proinflammatory effects of particles on macrophages and epithelial cells. In: Donaldson K, Borm P, editors. Particle toxicology. Boca Raton: CRC Press/Taylor \& Francis Group; 2007. p. 183-96.

6. Ishihara Y, Nagai A, Kagawa J. Comparison of the effect of exposure to filter cigarette and nonfilter cigarette smoke in rat bronchoalveolar lavage fluid and blood: the antioxidant balance and protease-antiprotease balance in vivo. Inhal Toxicol. 1997;9(3):273-86.
7. Gilmour MI, Stevens T, Saxena RK. Effect of particles on the immune system. In: Donaldson K, Borm P, editors. Particle toxicology. Boca Raton: CRC Press/Taylor \& Francis Group; 2007. p. 245-57.

8. Dziedzic D, Wheeler CS, Gross KB. Bronchoalveolar lavage: detecting markers of lung injury. In: Corn M, editor. Handbook of hazardous materials. San Diego: Academic Press; 1993. p. 99-111.

9. Hurbánková M, Černá S, Beňo M, Wimmerová S, Moricová Š. The influence of cigarette smoke on the selected bronchoalveolar cells in experiment. Cent Eur J Public Health. 2012 Mar;20(1):54-7.

10. Beno M, Hurbankova M, Dusinska M, Cerna S, Volkovova K, Staruchova $\mathrm{M}$, et al. Multinucleate cells (MNC) as sensitive semiquantitative biomarkers of the toxic effect after experimental fibrous dust and cigarette smoke inhalation by rats. Exp Toxicol Pathol. 2005 Aug;57(1):77-87.

11. Sjöstrand M, Rylander R, Bergström R. Lung cell reactions in guinea pigs after inhalation of asbestos (amosite). Toxicology. $1989 \mathrm{Jul}$ 3;57(1):1-14.

Received March 23, 2013 Accepted in revised form June 27, 2014 